\title{
Tom Phillips
}

\section{Touch and Voice: Horace's Odes}

The voice of Horace's Odes has been variously conceptualized in modern scholarship. It has emerged by turns, to reference just a few of the more prominent trends, as a layered, reflective, and often ironic persona, ${ }^{1}$ a kaleidoscopic refraction of the political and aesthetic tensions inscribed in the traditions in with which Horace worked, ${ }^{2}$ a mechanism for literary historical and socio-political self-positioning, ${ }^{3}$ and a figure through which the poet aims to transcend the material limitations of the poetry book. ${ }^{4}$ Building on these discussions, this paper approaches a subset of Horace's Odes in terms of the possibilities they create for vocal delivery. ${ }^{5}$ The hinge on which these possibilities turn is a connection between two forms of embodied materiality, the voice and haptic experience.

\section{Frameworks}

Horace's readers lived in a literary culture to which ideas of the voice, and attempts to theorize what occurs in the process of voiced reading, were of central importance. ${ }^{6}$ Hellenistic and Roman thinking about the voice paid considerable attention to the materiality of language and the forms of affectivity it generated, ${ }^{7}$ but equally salient

1 See e. g. Harrison 2007a, with further references.

2 Important treatments include Fowler 1995; Lowrie 1997; Oliensis 1997.

3 I give here only a very selective survey of the extensive secondary literature. General analyses: Davis 1991; Harrison 2007b, 168-206; Engagement with Greek predecessors is especially important to Horace's lyric self-consciousness: see e. g. Feeney 1993; Barchiesi 1996; Barchiesi 2000; useful overviews in Hutchinson 2007; Clay 2010.

4 Lowrie 2009, esp.117-121.

5 My position here is not premised on the assumption that ancient readers always read aloud: for discussion of this issue and further references see Phillips 2016, 19-23. My readings are concerned primarily with scenarios that involved vocalization of the poems, whether public or private, but they also bear on silent reading insofar as this activity would have involved readers imagining the poems' vocal expressiveness. On recitation in Rome, see e. g. Lowrie 2009, 83-86.

6 For a synopsis of ancient theorizing about the voice see Porter 2009; and at greater length, Porter 2010, 308-364.

7 Critical engagement with language's sonic features was especially pronounced in the work of the 'euphonist' literary theorists such as Andromenides, Pausimachus, and Crates of Mallos, whose valuations of literary texts were based on the primacy of sound as a criterion. For Crates' views about vocal

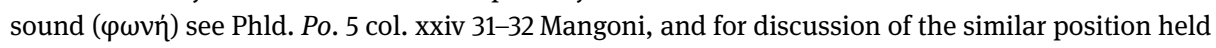

I am grateful to Rich Rabone and Tim Rood for comments on a draft of this chapter, and to the audience at the Zurich conference for stimulating discussion. All translations are my own.

Ә Open Access. () 2019 Tom Phillips, publiziert von De Gruyter. (c) BY-NC-ND Dieses Werk ist lizenziert unter der Creative Commons Attribution-NonCommercial-NoDerivatives 4.0 Lizenz.

https://doi.org/10.1515/9783110641042-011 
in readers' conception of their activity will have been conceptualizations of style in terms of its ethical significance. The notion that the stylistic features of a work approximate character, pithily captured in Seneca's dictum talis hominibus fuit oratio qualis vita (Sen. epist. 114,1), goes back at least to the fifth-century, ${ }^{8}$ and was one of the most common analytical gestures of ancient literary criticism. ${ }^{9}$ In giving voice to Horace's poems, readers will have been conscious of the notion that their activity could be conceived, at least in part, as a performance of and encounter with the form of selfhood embodied in a poem's stylistic textures.

A series of intersections between style and ethicality in Horace's Odes is the focus of this paper. Analysing what such intersections might have meant for Roman readers entails confronting complex interactions between the frameworks for thinking about this intersection provided by extant ancient theoretical writings, and the poems themselves. Dionysius Thrax's analysis of voiced reading is a useful pointer in this respect.

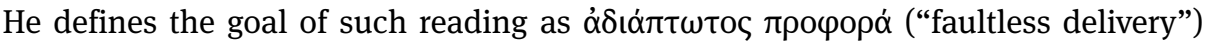
(Grammatici Graeci i 1,6), and holds that such "delivery" can only come about as a result of the reader's correct evaluation of syntax and meaning, which enables the rec-

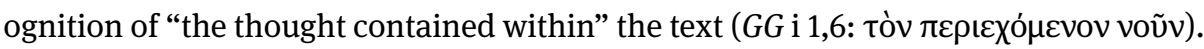
Elaborating on this position, he holds that particular tones of voice are appropriate to certain poetic modes: elegy should be read "clearly", epic "boldly", while a "melodic"

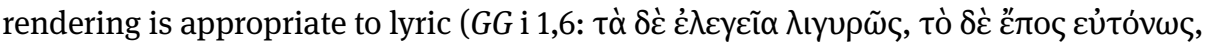

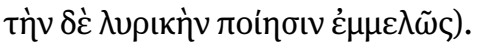

Even leaving aside the hermeneutic problems of inferring "the thought contained within" a particular text, this passage is at most an adumbration of what might occur in particular acts of reading. The specific meaning of $\varepsilon \mu \mu \varepsilon \lambda \tilde{\omega} \varsigma$ is disputed, ${ }^{10}$ but what is clear is that Dionysius' analysis works at a high level of generality, and that the

by Pausimachus see Janko 2000, 165-189. On the hierarchy of sounds, used by e. g. Dionysius of Halicarnassus and Ps.-Demetrius as a means of stylistic classification and judgement in their analyses of the quality of sonic arrangement ( $\sigma \dot{v} v \theta \varepsilon \sigma \iota \varsigma)$, see Janko 2000, 177-178. For further discussion of sound in Horace see below p. 198.

8 Perhaps the most famous instance being the congruence between poetics and politics embodied in the Aeschylus and Euripides of Aristophanes' Frogs: for discussion of the play's relation to later literary criticism see Hunter 2009, 10-52.

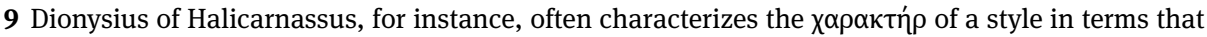
fold together the aesthetic and the ethical: the "harsh style", for instance, is "high-minded, forthright,

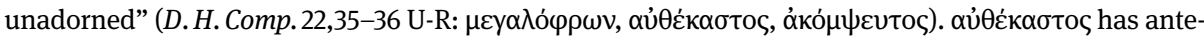
cedents in Aristotelian ethics: see Arist. EN 1127a23-26; EE 1233b39-40. Horace also meditates on the character-forming aspects of poetry in his literary critical writing: see esp. epist. 2,1,126-138.

10 The comment in $\Sigma^{\theta}$ ad D. T. = GG i 3,21 Hilgard that "lyric poetry must be read with a melody, even if we do not have or do not remember the poets' melodies" shows that $\varepsilon \mu \mu \varepsilon \lambda \tilde{\omega} \varsigma$ cannot refer to "original” melodies preserved in musical scores: see Prauscello 2006, 51-58 for further discussion. D'Angour 2007, 294 argues that $\varepsilon \mu \mu \varepsilon \lambda \tilde{\omega} \varsigma$ refers to the reader's role in articulating melodic structures latent in the pitch-structure of the words; if this is right, the precise qualities such renderings would have been affected by other aspects of delivery. For discussion of Dionysius' formulations in relation to reading 
"melodic" qualities of a given reading would have been affected by numerous factors particular to a given text (tone, phrasal structure, rhythm, vocabulary) and by the reader's decisions about how these features were to be understood and translated into "delivery" (actio). The variousness of the vocal possibilities that a particular poem might open up are suggested in Cicero's reflections on actio:

Est enim actio quasi corporis quaedam eloquentia, cum constet e voce atque motu. Vocis mutationes totidem sunt quot animorum, qui maxime voce commoventur. Itaque ille perfectus, quem iamdudum nostra indicat oratio, utcumque se adfectum videri et animum audientis moveri volet, ita certum vocis admovebit sonum [...].

For delivery is as it were a certain eloquence of the body, since it consists of voice as well as movement. There are as many variations of the voice as there are of the feelings, which are especially moved by the voice. Therefore the complete orator, whom our speech has now for some time been delineating, will employ a certain tone of voice according to how he wishes to appear to be moved himself and to how he wishes to move the minds of his listeners [...].

(Cic. orat. 55)

Like speeches, poems call for multiple, shifting "variations of the voice". But whereas the orator uses variations in tone in order to sway his audience, the reader's vocis mutationes and decisions about sonus will reflect the mutationes of "feeling", register, and content inferred from a text. ${ }^{11}$

Poems also have less defined affective aims than Cicero gives to speeches here. While emotiveness (animum audientis moveri) is an important consideration, my readings here concern passages in which Horace creates indirect relations between textual figurations of experience and concrete acts of voicing. The result is that the mutationes and sonus these figures might produce are the products of individuals' interpretative and emotional encounters with the poems, rather than features that can be straightforwardly inferred on the basis of critical norms. Horace's self-representations in these passages can be productively viewed as affordances that seek to shape how the poems are delivered and inhabited as vocal artefacts, but that also entail larger reflections on poetry's capacities to inform the self, create fictional domains, and elicit imaginative

in schools see Mitchell 2015. Their possible relevance to Horace is explored at p. 198f. On the voice in ancient rhetoric in general see Schulz 2014.

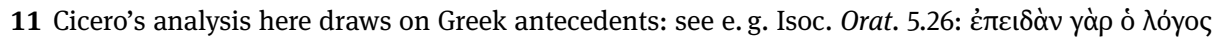

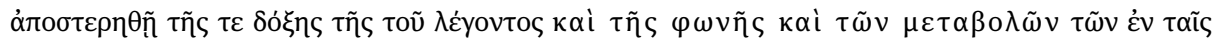

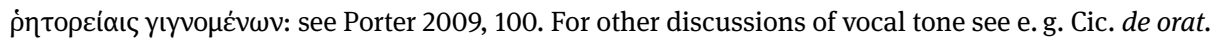
3,41-42,174,216. Rhet. Her. 3,23-24 gives a detailed account of the mollitudo vocis and how it should be deployed in order to fit with the contents and aims of a speech. A reader giving a recitatio could of course have modulated his reading in the manner Cicero describes, and notions of dramatization might well have affected the practices of private reading as well, insofar as readers' familiarity with the 'dramatic' features of delivery would have easily facilitated a conceptualization of themselves as an audience for their own actio. 
identification. ${ }^{12}$ In accommodating themselves to the passages' vocal potentialities and considering their implications, readers are invited to reflect on the transformative power of the encounters the poems create.

\title{
2 Touch, Voice, Meaning
}

Critics have often been puzzled, and sometimes repelled, by Horace's metamorphosis into a swan in carm. 2,20, and more specifically by the focus on the process of bodily transformation in $9-12:^{13}$

\author{
Iam iam residunt cruribus asperae \\ pelles, et album mutor in alitem \\ superne, nascunturque leves \\ per digitos umerosque plumae.
}

Even now, rough skin is forming on my legs; I am changing into a white bird in my upper part, light feathers are sprouting from finger to shoulder.

(Hor. carm. 2,20)

The swan is a commonly employed as a metapoetic metaphor, and Horace's version is charged with various literary and philosophical associations. ${ }^{14}$ There remains something insistently odd, however, both about the description itself, the sensuous specificity of which exceeds that of its models, and its placement, bracketed by a very unswan-like address to Maecenas and by a flight that owes more to contemporary history than to myth or ornithology. ${ }^{15}$

12 My use of affordance here approximates that of Felski 2015, 164-165, who uses it to name the ways in which texts' formal features open up experiential and interpretative possibilities. For a cognitively-inflected treatment of "literary affordances" see Cave 2016, 46-62.

13 See Harrison 2017, 237-238 for an overview and further references.

14 The swan is not named in the poem but the identification seems secure: for this, and other passages in which swans and poets/poetry are connected see Nisbet and Hubbard 1978, 342. Important readings of Horace's swan: Thévenaz 2002; Erasmo 2006 on the poem's Ennian antecedents; Schiesaro 2009, 67-72 focuses on the combination of Callimachean intertexts (in particular e. g. Aet. fr. 1,36

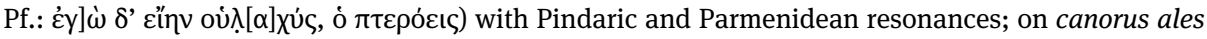
(Hor. carm. 2,20,15-16) and Prop. 2,34,83-84 see Pianezzola 2013. Harrison 2017, 236-237 points out other connections, including with Posidipp. fr. 118 A-B.

15 The latter both well captured, although with different conclusions, by Fraenkel 1957, 301-302 (with older bibliography), and elaborated by West 1998, 145 for whom the metamorphosis is constituted by "physiological embarrassments" productive of a humour that "renders acceptable" Horace's claims for his poetry (a emphasis on humour is not inapposite: cf. Harrison 1988 on Horace's own deflation of carm. 2,20 in epist. 1,20). See also Harrison 2007a, 30 on the "jarringly literal" image, and Nisbet and Hubbard 1978, 334, stressing the metaphor's conventionality. On the topicality of Horace's journey see Nisbet and Hubbard 1978, 346. 
This oddness is, I think, something the passage aims at, and is symptomatic of the physical qualities of the metamorphosis resisting any purely allegorical reading. The effects that this resistance creates, to which I shall return below, are closely related to another feature of the poem. Elsewhere, the swan's metapoetic valence is closely connected to its song, ${ }^{16}$ but with the exception of Horace's characterization of himself as a canorus ales at 15-16, the swan's music is conspicuous by its absence from the poem. The absence creates an indirection between the figuration of the poetic voice and the poem's potential vocal realizations that picks up on a similar development in carm. 2,19.

As commentators have often noted, the picture of Bacchus teaching the nymphs and satyrs with which 2,19 begins acts as a partial proxy for Horace's own poetic activity:

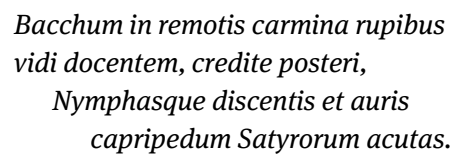

I saw Bacchus on distant cliffs (believe me, men of the future) teaching his songs, and the nymphs learning them and the pricked-up ears of the goat-footed satyrs.

(Hor. carm. 2,19)

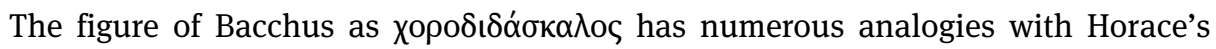
self-representation, ${ }^{17}$ but the suggestion that the nymphs and satyrs will perform Bacchus' carmina chorally reminds us that Horace's poems as verbal artefacts generate their effects through different media-book, reading, and voice. The particularities of the latter are brought to the fore in the tonal complexity of credite posteri, which combines irony (the very demand underscores the incredibility of the literal claim) with an implicit demand for readerly assent to the poem, whether that takes the form of "believing" in the text's allegorical implications or assenting to the text's momentary creation of a fictional world. ${ }^{18}$ In raising these interpretative considerations, credite posteri sets up a problematic demand for a vocal realisation responsive to both the poem's self-consciousness and its subject matter.

The problem of voicing is brought to the fore again when the language of song is picked up in the third stanza:

16 On the beauty of the dying swan's song see e.g. A. A. 1444-1446; Pl. Phd. 84e, and Nisbet and

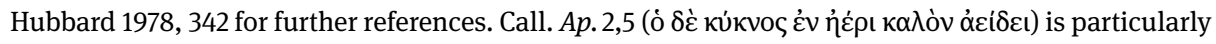
significant for Horace's appropriation: see Schiesaro 2009, 68-72.

17 Most obviously, it recalls Hor. carm. 1,1,29-32; for other parallels see Harrison 2017, 225-226.

18 For allegorical readings with reference to the political resonances of Bacchus in the 20s BC see e. $g$. Stevens 1999; Harrison 2017, 225 with further references; on the ironies of the opening see e. g. West 1998, 138-140. 
Fas pervicacis est mihi Thyiadas

vinique fontem lactis et uberes

cantare rivos atque truncis

lapsa cavis iterare mella [...].

It is right for me to sing the tireless Thyiades, and fountains of wine and rills rich with milk, and to repeat the tale of the honey sliding down the hollow trunks [...].

(Hor. carm. 2,19,9-12)

The use of cantare here does not simply assert poetic authority, but suggests a question about the kind of song-like and melodic quality the poem might be said to achieve. ${ }^{19}$ In the context of a lyric appropriation of a tragic motif, ${ }^{20}$ cantare recalls Dionysius Thrax's distinctions between the forms of "delivery" ( $\pi \rho \circ \varphi \circ \rho \dot{)})$ apposite to different poetic modes, suggesting not just the poet's genre-specific writing but the kind of "melodic" ( $\dot{\varepsilon} \mu \mu \varepsilon \lambda \tilde{\omega} \varsigma)$ reading apposite to the passage. ${ }^{21}$ That such a vocal response would be reflecting the text's sonic properties as well as its enchanting content is accentuated by the alliterative musicality of lapsa cavis iterare mella. According to various Hellenistic theories of language, ' $\lambda$ ' was considered especially euphonic, ${ }^{22}$ and similar points are made about ' 1 ' by Roman authors. ${ }^{23}$ For readers familiar with such thinking, lapsa ... mella would have created a particular coincidence between the qualities of referent and language. Moreover, by encouraging voicing attuned to these qualities, the poem calls attention to the way in which its song-like status might be enacted by the translation of its discursive capacities into real-world embodiments.

19 For discussion of Horace's use of the language of song to both stake claims to authority and problematize their realisation, see Lowrie 2009, 111-117. On her reading, "Horatian lyric falls between full enactment and [...] fiction" (p.115).

20 The stanza recalls inter alia E. Ba. 142-143 and 707-711.

21 Readers who recalled Dionysius' remarks would clearly not have applied them in the same way to Latin as to Greek, particular if D'Angour 2007, 294 is correct to argue that $\dot{\varepsilon} \mu \mu \varepsilon \lambda \tilde{\omega} \varsigma$ refers to pitch-structure (see above p. 194). My argument here is that, in alluding to Dionysius Thrax's schema, Horace is not suggesting a definite type of "melodic" rendering, but rather inviting engagement with the expressivity of the poem as a sonic artefact. This might well have been augmented by the congruity between laps $a$ and the suggestion of movement in the line's preponderance of short syllables.

22 Andromenides is cited by Philodemus as describing $\lambda$ as the "most resplendent" (Po. $1 \mathrm{fr}$. 21,9 Janko: ${ }_{\downarrow} \lambda \alpha \mu \pi \rho \dot{\tau}_{\jmath}[\alpha]$ Țov) of the letters; cf. D. H. Comp.14,102 U-R where it is the "sweetest" of the con-

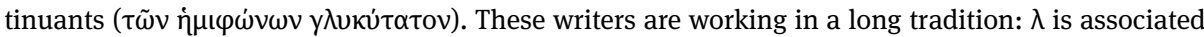

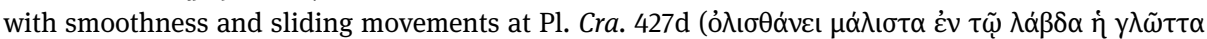

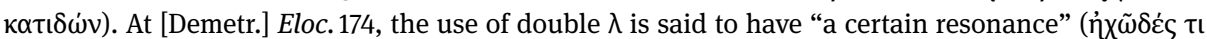
$\varepsilon \not \chi \varepsilon l)$ which contributes to its euphonic quality. For further references and discussion see Janko 2000 , $175-178$.

23 See e. g. (postdating Horace) Aug. dialect. $6=$ FDS 644 where mel itself is discussed: $q$ quam suaviter gustum res ipsa, tam leniter nomine tangit auditum. Cf. also the sonic qualities of lana and luna characterized as leves at Varro fr. 113 Goetz-Schoell. 
In this poem, therefore, the choral Bacchus of the opening stanza does not programme the poem's vocal poetics so much as adumbrate a frame within which Horace will create particular connections between form and meaning, which afford varied vocal possibilities for readers. In turn, the obliqueness with which carm. 2,20 acts as a template for vocalization continues and heightens that of 2,19. Despite several nods to vocal delivery, ${ }^{24}$ no direct claims about the poem's euphonic quality are presented in 2,20. Equally, for all their metapoetic and ethical suggestiveness, the latter poem's intertexts (swan-related and otherwise) do not make any strong assertions about the tone or style of delivery ( $\pi \rho \circ \varphi \circ \rho \alpha \dot{\alpha}$; actio) apposite to the poem. ${ }^{25}$ What I want to suggest here is that the physical specificities of the transformation, and the attention they compel from readers, are meant to inform the processes of voicing. In doing so, they pick up on a series of references to touch earlier in the book, but they also constitute an indirect yet powerful conduit between metapoetic claims and realizations of the poem in acts of reading: the effects created by the terms in which the former is couched are made manifest in the forms of "delivery" the poem occasions. In order to explore this effect, I focus first on the dynamics of the passage itself before turning to the larger thematics of touch to which it relates.

In contrast with the futures of the first two stanzas (1: ferar; 5: relinquam; 7: obibo; 8: cohibebor) and the description of the journey (14: visam; 19: noscent; 20: discet), the transformation is couched in the present tense. The phrase iam iam stresses that the events are occurring simultaneously with the moment of utterance, ${ }^{26}$ and residunt, mutor, and nascuntur have imperfective force, describing processes rather than instantaneous events. ${ }^{27}$ These imperfective presents facilitate visualisation by stressing that the event is ongoing, and opening it up to mental scrutiny. ${ }^{28}$ In the phrase

24 See e. g. Hor. carm. 2,20,6-7: quem vocas, / dilecte Maecenas, which hints at voiced reading without making clear what the character of that voicing might be; Harrison 2017, 238 points out that ferar $(2,20,1)$ "applies equally well to bird, book, and poet [...][suggesting] future verbal voicing in recitation". It might be relevant that the coronides that marked the end of poetry books often came in the form of birds: see Stephen 1959, 4; Hordern 2002, 72-73 and 94. Horace's swan might therefore be read as alluding to the physical form of (some) canonised books: the possibility is noted with scepticism by Eidinow 2009, 87 n. 27.

25 N. b. the elusiveness of nec tenui ferar (Hor. carm. 2,20,1) in this respect, discussed by Schiesaro 2009, 72, who reads it as encoding a turn away from Callimachean delicacy in order to accommodate the image of "a powerful vates who relishes Pindar's sublimity”; see also Harrison 2017, 238. Crucially,

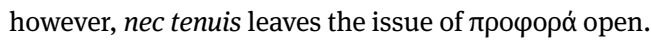

26 See Harrison 2017, 240.

27 Nisbet and Hubbard 1978, 341 comment that residunt might "hint at [Horace's] own physical deterioration", comparing Iuv. 10,192, where pellis is used of an old man. If apprehended, this undertone would reinforce the imperfective sense by referencing the extended process of ageing. Irony is heightened by asperae recalling Aristotle's view that "people with hard flesh are poorly endowed with

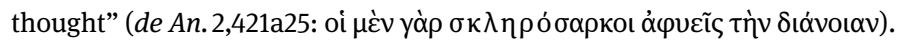

28 On this feature of the imperfective present see Fleischman 1990, 35-37. 
album mutor in alitem, the telic verbal expression points to a specific end-point, ${ }^{29}$ but is offset by the imperfective sense, which stresses the action's indefinite duration. The lines' syntactical emphasis on duration coheres with their visual detailing, and impels heightened imaginative attention.

As well as registering the intensity of the imagined experience, the syntactical and ecphrastic invitation to linger over these lines suggests that the mechanics of the metamorphosis are significant in themselves, over and above their figurative implications. Readers watch the literalization of metapoetic vocabulary creating a moment of haptic juncture, of one body being touched by and becoming another. ${ }^{30}$ This juncture realizes a moment at which sensory experience enables a disclosure of self-understanding, which has narrower and broader ambits. The passage conveys the sense that poetry affords a transcendence of human constraints by allowing the poet's body to be translated into other forms (voice, book, meaning), but the vocabulary recalls the limitations of the ageing human body. ${ }^{31}$ Yet as a reflection of poetry's transformative powers, the passage also suggests that such moments of juncture are characteristic of the heightened way of relating to the world that poetry and an engaged reading of poetry constitute.

The swan metamorphosis is the culmination of a series of haptically inflected passages in Odes 2. At carm. 2,4,21-22 Horace looks admiringly at Phyllis: bracchia et vultum teretisque suras / integer laudo: fuge suspicari ("I praise her arms and face and slender ankles-disinterestedly! Don’t be suspicious!”). Horace's age keeps him integer (22-24), but the bodily detailing of 21 is a reminder of the allure of touch that the speaker rejects as a condition of maintaining this status. ${ }^{32}$ At carm. 2,12, Licymnia's erotic allure is represented through a play of contact and deferral: $:^{33}$

29 Telic verbs describe actions that have an end-point inherent to their sense: for further discussion see Comrie 1976, 44-48; Binnick 1991, 194-197.

30 Although the vocabulary of touch is not explicitly employed, haptic sensations are implicit in asperae / pelles, which conveys the speaker's sense of the difference between his former body and that of the swan; leves ... plumae creates a similar effect.

31 Translation: see above n. 24; vulnerability of the body: $n .27$.

32 This indirection continues into the first stanza of Hor. carm. 2,5, in which the young Lalage is "not yet strong enough to bear the yoke" (1: nondum [...] ferre iugum valet) or "endure the weight of the bull rushing to mate" (3-4: tauri ruentis / in venerem tolerare pondus). Here, the acts of touch involved in sex are framed in the conventional terms of Greek erotic lyric: for the intertexts with Anacreon and other models, see Harrison 2017, 83-86. For all its conventionality and implications of assertive masculine sexuality (for which see e. g. Nisbet and Hubbard 1978, 81), this translation of human into non-human sets in train the poem's complication of sexual identities and practices: Lalage herself will assume the active role at first occupied by the male addressee (13: iam te sequetur), and the muscular definiteness of the first stanza's imagery gives way to "images of obscurity and imprecision" (Oliensis 2002,97 ) in the final lines (23-24: discrimen obscurum [...] ambiguoque vultu).

33 Licymnia was identified by [Acro] ad sat. 1,2,64 with Maecenas' wife, Terentia: see Nisbet and Hubbard 1978, 180-182; Harrison 2017, 148 is rightly sceptical.; see further Curtis 2017, 118. 


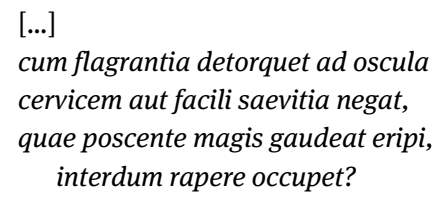

[...] when she bends her neck to your burning kisses, or sometimes refuses them with mock savagery, those kisses which, even more than he who demands, she loves to be stolen, and sometimes is the first to seize them.

(Hor. carm. 2,12,25-28)

The description completes the poem's turn away from warfare as a potential subject, ${ }^{34}$ but military undertones run through the language of flagrantia, saevitia, eripi, rapere, and occupet, ${ }^{35}$ suggesting different ways of reading Licymnia's haptic choreography. Do her gestures and responses successfully sublimate or displace the violence of the opening three stanzas, ${ }^{36}$ or do they, like the words used to describe them, necessarily carry with them disquieting reminders of the body's propensity and vulnerability to disorder? Semantic ambivalence also accentuates the language's oblique conveyance of the sensations and significances transmitted by touch. Maecenas experiences Licymnia's kisses not only as a sensuous plenitude, but also as an intuitively-grasped index of their relationship as a whole. For readers, by contrast, this plenitude and its wider context can only be grasped through fleeting if intense synecdoche (flagrantia), and through the ambivalent implications of the language into which the scene's gestures are transmuted. ${ }^{37}$

Touch, then, is productively problematic in these passages. It is a sense that brings into question the distinction between self and other, in which "we are both touched and touching at the same time", ${ }^{38}$ and thus threatens bodily integrity and self-control.

34 For discussion of the poem as a recusatio see Nisbet and Hubbard 1978, 179-183.

35 Flagro and its cognates are often used of the emotions, but can also see also e. g. Cic. Att. 7,17,4: totam Italiam flagraturam bello intelligo. Saevitia recalls the behaviour of the elegiac puella (e.g. Prop.1,3,18: metuens iurgia saevitiae), but c. f. also e. g. Sall. Iug. 7,2 for its use of enemies in war. For eripio in military contexts see e. g. Caes. Gall. 6,30,2 and civ. 3,111,4. Rapere is of course common of brigandage: see e. g. Sall. Cat. 11,4. For occupet in battle scenes cf. Verg. Aen. 9,770 and 10,699.

36 A series of haptic references create a movement of graduated diminution of violence; at 6-7 the earthborn are "vanquished by Heracles' hand" (domitosque Heraclea manu / telluris iuvenis), while at 18, Licymnia "links arms" in the choral dance (dare bracchia); Harrison 2017, 154 also notes that ceruicem (26) picks up and reverses the "necks of menacing kings" (12: regum colla minacium). This sequence enacts a movement from violence to the civilized, but it also underscores the dependence of civilized intimacy on the proelia Caesaris (10).

37 In this sense, the replication of expressivity suggested by cantare is, or at least reaches towards being, an "empirical contact with the world" (Porter 2013, 20).

38 Kearney 2015, 103; see also Purves 2013, 28-30 for further discussion of the philosophically problematic nature of touch for Aristotle. Touch in Propertius, Horace and Ovid is considered by RitterSchmalz, this volume. 
Yet even when remembered, put at a distance, or turned into metaphor, it also enables fine-grained engagement with the world. For Aristotle, touch is "the most accurate" mode of perception, and man's capacity to sense differences through this medium is superior to other animals'. ${ }^{39}$ Passages such as the final stanza of carm. 2,12 foreground moments of haptic contact that engage the self (both reader and character) in forms of embodied understanding, while also thematizing the access to such moments that poetry affords.

This thematization is instantiated again in the haptic encounter between Bacchus and Cerberus that closes 2,19. Here, Cerberus' fawning indexes the god's bewitching power:

\author{
Te vidit insons Cerberus aureo \\ cornu decorum leniter atterens \\ cauda et recedentis trilingui \\ ore pedes tetigitque crura.
}

Cerberus saw you decked out with your golden horns, and did you no harm; he rubbed softly against you with his tail, and as you turned away touched your feet and legs with his threetongued mouth.

(Hor. carm. 2,19,27-30)

Like the final stanza of carm. 2,12, these lines foreground the complex indirectness of the relationship between the text and the embodied meaningfulness experienced through touch and gesture by the actors in the scene. The passage also anticipates the dynamics of the swan metamorphosis, both being characterized by an abundance of physical detailing that exceeds the texts on which they are modelled..$^{40}$ Here, details

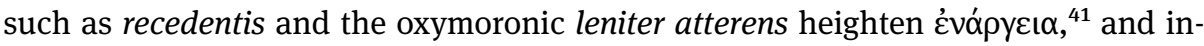
vite readers to infer and imagine the scene's sensory qualities, but the stanza also foregrounds the different sensory and intellectual modalities involved in the act of reading and the scene itself. ${ }^{42}$ Yet far from throwing an insuperable barrier between

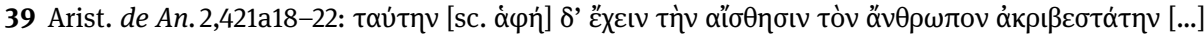

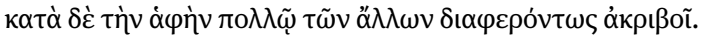

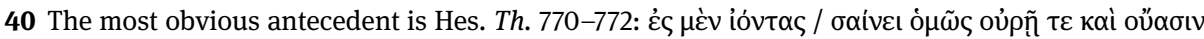

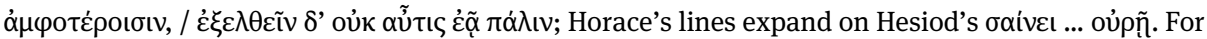
comments on the wider connections between Hor. carm. 2,19 and 2,20, see Santirocco 1986, 107-108; Schiesaro 2009, 72 .

41 See Harrison 2017, 234, where the textual issue relating to cauda is also treated.

42 Most obviously, readers are positioned as 'spectators' of the scene rather than participants. This differentiation is given further point by the contrast between haptic immediacy, in which the relationship between the two actors is enacted by its embodiment, and the relationality of intertextually-inflected meaning; recall of Hesiod's lines and comparison of them to Horace's also entails a process the duration of which contrasts with the instantaneousness of Cerberus' encounter with Bacchus. The contrast is not absolute, however, in that the lines' intertextual differentiation could also be read as analogizing the sensing of differences by which particular haptic sensations are distinguished from others. 
the events of the fabula and their textual realization, the complexities of access challenge readers to generate in their voicing of the text ( $\pi \rho \circ \varphi \circ \rho \alpha)$ a tonal and affective

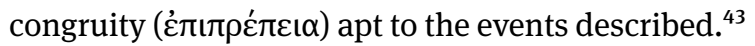

The imaginative task of making vocal textures cohere with imagined hapticities anticipates the metamorphosis of 2,20, which can be read both as a culmination and a further complication of this sequence of passages. In 2,12, we are shown two people touching, in 2,19 two animals; in 2,20, a person is touched by an animal that he is in the process of becoming. ${ }^{44}$ The demands made on the reader's imaginative engagement are similarly greater in 2,20, but balanced by obvious irony: neither Horace nor the reader actually become a swan. Instead, the passage talks about intensity of experience in coded terms. This codedness is a discursive enactment of ethical restraint, but also prompts readers to undergo the imaginative work of correlating themselves with the process (rather than the actuality) of change dramatized in the metamorphosis. In responding to the poem, readers are challenged to imagine what it would be like to undergo such a metamorphosis, and to give voice to the stanza in a manner adequately responsive to it.

This relation between metamorphosis and responsive voicing is not straightforward, however. Unlike some other poetic texts dealing with animals, Horace's lines are not mimetic of the swan's particular physicality. ${ }^{45}$ Equally, just as the singular quality of the lines cannot be circumscribed by their intertextual filiations, they sit uneasily with literary critical reflections on "delivery", posing the question of what sort of $\pi \rho о \varphi о \rho \alpha$ might be commensurate with the experience of the metamorphosis. The tonal difference between carm. 2,20,9-12 and the stanzas that flank it encourages an intensity of expression geared to its unsettling strangeness. ${ }^{46}$ Phrasing such as iam iam residunt, mutor, and nascuntur can be voiced with a sense of surprise, shock,

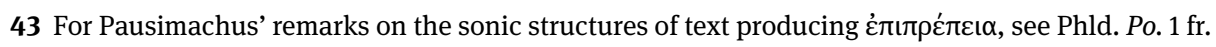
114,15-18 Janko, with discussion and parallels at Janko 2000, 327 n. 9.

44 This ambivalent status is highlighted in the phrasing of biformis vates (2-3).

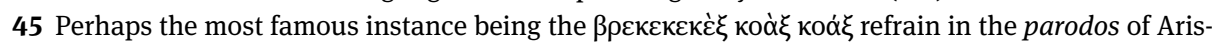
tophanes' Frogs; see also Payne 2013, 49-51 on the Cynegetica. Moreover, Horace's metrical effects stylise focalization rather than being mimetic of their referents. The long syllables of nascunturque leves (- - - - -), for instance, reinforce the effect of immersed perception described above: for the "holding" and "delaying" quality of long syllables, see D. H. Comp.20,73-80 U-R. The lighter movement of per digitos umerosque plumae (- $--\smile--\smile--$ ) might suggest the lightness of the feathers or the speed with which they spread up the arm, but such a suggestion is more implicit than the congruities of rhythm and sense that Horace generates elsewhere: contrast, for instance, carm. 3,13,1-2 (o fons Bandusiae / splendidior uitro) with the comments of Fitzgerald 1989, 98: "[the lines] set up a relation between speaker and spring that is not so much responsive as reflecting [...] the speaker constitutes the spring as an object that throws back his own voice just as it does the light, so that the final syllable of vitro echoes the " $O$ " of the apostrophe". The lines achieve a translucent reflection of referent by form, in which "the "O" that is the pure voice of encounter is thrown back at the speaker" (Fitzgerald 1989, 98).

46 There is a marked shift of register from the large-scale picture of the Styx (8: nam Stygia cohibebor 
amused knowingness, or a combination thereof, ${ }^{47}$ or with a more or less strong acknowledgement of the impossibility of capturing the denoted experience in a vocal comportment. Whatever the precise calibrations of a particular delivery, the ecphrasis of the changing body is registered in the voice's haptic engagement by the text, by the movements of mouth and breath through which the poem is realized as well as by its imaginative and hermeneutic promptings. Horace achieves metamorphosis into the vocal intensity and attitude the lines elicit.

\section{Conclusions}

On the readings I have advanced, Odes 2,19 and 2,20 promote experiential engagement as much as hermeneutic activity. The poem's effects call for a responsiveness that goes beyond the analytical stance implicitly attributed to the reading subject in many contemporary readings of Horace's self-representation, in which metapoetic figures are observed at an analytical remove. ${ }^{48}$ Being alive to and engaged in the ways poetic texture affords vocal possibilities entails a concern with drawing these figures into the reader's own experiential orbits, and reflecting on what it might mean for versions of them to be enacted in the reader's self-understanding. Grasped in these terms, the swan metamorphosis in 2,20 operates as much as an experiential and ethical affordance as a paraphrasable proposition. We can easily 'translate' the figure of the swan into propositional content, understanding it as a metaphor for the poet's transcendence of human limitations. But the poem also asks to be encountered as a form of subjectivity, rather than a verbal artefact, that operates through its extension in the reader's ethical life. The poem is a comment on the receptive conditions that potentiate poetic immortality as much as an assured statement of its occurrence.

Recent scholarship has engaged productively with questions relating to the material instantiation of Horace's odes. The question of performance remains fascinatingly problematic, ${ }^{49}$ while our understanding of the structures and materiality of the poetry book as a significant object has increased significantly. ${ }^{50}$ A sensitivity to voiced reading as a means of registering and translating moments of haptic experience, and reflecting the forms of conduct and understanding that such experiences embody, offers

unda) to the physical immediacy of iam iam residunt; this is paralleled by the movement from the intimacy of verse 12 to the semi-mythological journey of nam Daedaleo notior Icaro (13).

47 Harrison 2017, 240-241 points out the surprise created by the postponement of plumae to sentence-end; see also Lowrie 1997, 213.

48 See e. g. Schiesaro 2009, 77-79.

49 For discussion see Lowrie 2009, 81-92; Habinek 2005 argues for the importance of 'song' as a category to Roman understandings of poetry; see also Wiseman 2015.

50 Structure: Lowrie 1995, Lyne 2003; materiality of the book: Eidinow 2009. 
a useful supplement to these approaches. ${ }^{51}$ According to the approach pursued here, material instantiations are not constraints to be transcended, but are configured into imaginative and vocal affordances that expand readers' imaginative engagement with the world.

\section{Bibliography}

Barchiesi, Alessandro (1996), “Poetry, Praise, and Patronage: Simonides in Book 4 of Horace's Odes”, in: Classical Antiquity 15 (1), 5-47.

Barchiesi, Alessandro (2000), "Rituals in Ink: Horace on the Greek Lyric Tradition”, in: Mary Depew and Dirk Obbink (eds.), Matrices of Genre: Authors, Canons, and Society (Center for Hellenic Studies Colloquia 4), Cambridge, 167-182.

Binnick, Robert (1991), Time and the Verb: A Guide to Tense and Aspect, New York.

Cave, Terence (2016), Thinking With Literature: Towards a Cognitive Criticism, Oxford.

Comrie, Bernard (1976), Aspect: An Introduction to the Study of Verbal Aspect and Related Problems, Cambridge.

Curtis, Lauren (2017), Imagining the Chorus in Augustan Poetry, Cambridge.

Davis, Gregson (1991), Polyhymnia: The Rhetoric of Horatian Lyric Discourse, Berkeley.

D’Angour, Armand (2007), "The Sound of Mousikē: Reflections on Aural Change in Ancient Greece", in: Robin Osborne (ed.), Debating the Athenian Cultural Revolution: Art, Literature, Philosophy, and Politics 430-380 BC, Cambridge, 288-300.

Eidinow, John (2009), “Horace: Critics, Canons, and Canonicity”, in: Luke Houghton and Maria Wyke (eds.), Perceptions of Horace, Cambridge, 80-95.

Erasmo, Mario (2006), "Birds of a Feather? Ennius and Horace, Odes 2,20", in: Latomus 65, 369-377.

Feeney, Denis (1993), “Horace and the Greek Poets”, in: Niall Rudd (ed.), Horace 2000: A Celebration, London, 41-63.

Felski, Rita (2015), The Limits of Critique, Chicago.

Fitzgerald, William (1989), “Horace, Pleasure, and the Text”, in: Arethusa 22 (1), 81-103.

Fitzgerald, William (2013), How To Read A Latin Poem: If You Can't Read Latin Yet, Oxford.

Fleischman, Suzanne (1990), Tense and Narrativity: From Medieval Performance to Modern Fiction, Austin (TX).

Fowler, Don (1995), “Horace and the Aesthetics of Politics”, in: Stephen Harrison (ed.) Homage to Horace: A Bimillenary Celebration, Oxford, 248-266.

Fraenkel, Eduard (1957), Horace, Oxford.

Habinek, Thomas (2005), The World of Roman Song, Baltimore (MD)/London.

Harrison, Stephen (1988), “Deflating the Odes: Horace, Epistles 1,20”, in: Classical Quarterly 38 (2), 473-476.

Harrison, Stephen (2007a), “Horatian Self-Representations”, in: Stephen Harrison (ed.), The Cambridge Companion to Horace, Cambridge, 22-35.

Harrison, Stephen (2007b), Generic Enrichment in Vergil and Horace, Oxford.

Harrison, Stephen (2017), Horace Odes Book II, ed., introd. and comm. by S. H., Cambridge.

Hordern, James (2002), The Fragments of Timotheus of Miletus, ed., introd. and comm. by J. H., Oxford.

51 Cf. the elegant analyses of the "sensation" created by the Odes in Fitzgerald 2013, 101-140. 
Hunter, Richard (2009), Critical Moments in Classical Literature: Studies in the Ancient View of Literature and its Uses, Cambridge.

Hutchinson, Gregory (2007), “Horace and Archaic Greek Poetry”, in: Stephen Harrison (ed.), The Cambridge Companion to Horace, Cambridge, 36-49.

Janko, Richard (2000), Philodemus On Poems, ed., introd., trans. and comm. by R. J., Oxford. Kearney, Richard (2015), “What is Carnal Hermeneutics?”, in: New Literary History 46 (1), 99-124. Lowrie, Michèle (1995), “A Parade of Lyric Predecessors: Horace Odes 1.12-18”, in: Phoenix 49, 33-48.

Lowrie, Michèle (1997), Horace's Narrative Odes, Oxford.

Lowrie, Michèle (2009), Writing, Performance, and Authority in Augustan Rome, Oxford.

Lyne, Ronald (2005), “Horace Odes Book 1 and the Alexandrian Edition of Alcaeus”, in: Classical Quarterly 55 (2), 542-558.

Mitchell, Jack (2015), "Literary Performance in the Schoolroom as Historical Reenactment: The Evidence of the Colloquia, Scholia to Canonical Works, and the Scholia to the Techne of Dionysius Thrax", in: American Journal of Philology 136, 469-502.

Nisbet, Robin/Hubbard, Margaret (1978), A Commentary on Horace: Odes Book Il, Oxford.

Oliensis, Ellen (1997), Horace and the Rhetoric of Authority, Cambridge.

Oliensis, Ellen (2002), "Feminine Endings, Lyric Seductions", in: Anthony Woodman and Denis Feeney (eds.), Traditions and Contexts in the Poetry of Horace, Cambridge, 93-106.

Payne, Mark (2013), “The Understanding Ear: Synaesthesia, Paraesthesia, and Talking Animals”, in: Shane Butler and Alex Purves (eds.), Synaesthesia and the Ancient Senses, Durham, 43-52.

Phillips, Tom (2016), Pindar's Library: Performance Poetry and Material Texts, Oxford.

Pianezzola, Emilio (2013), “Orazio: l’ode 2,20. Autoironia e autobiografia della sphragís”, in: Andrea Balbo, Federica Bessone, and Ermanno Malaspina (eds.), Tanti affetti in tal momemto: Studi in onore di Giovanna Garbarino, Alessandria, 685-692.

Porter, James (2009), “Rhetoric, Aesthetics, and the Voice”, in: Erik Gunderson (ed.), The Cambridge Companion to Ancient Rhetoric, Cambridge, 92-108.

Porter, James (2010), The Origins of Aesthetic Thought in Ancient Greece: Matter, Sensation, and Experience, Cambridge.

Porter, James (2013), “Why Are There Nine Muses?”, in: Shane Butler and Alex Purves (eds.), Synaesthesia and the Ancient Senses, Durham, 9-26.

Prauscello, Lucia (2006), Singing Alexandria: Music Between Practice and Textual Transmission (Mnemosyne. Supplementum 274), Leiden/Boston.

Purves, Alex (2013), “Haptic Herodotus”, in: Shane Butler and Alex Purves (eds.), Synaesthesia and the Ancient Senses, Durham, 27-42.

Santirocco, Matthew (1986), Unity and Design in Horace's Odes, Chapel Hill (NC)/London.

Schiesaro, Alessandro (2009), “Horace's Bacchic Poetics”, in: Luke Houghton and Maria Wyke (eds.), Perceptions of Horace: A Roman Poet and his Readers, Cambridge, 61-79.

Schulz, Verena (2014), Die Stimme in der antiken Rhetorik (Hypomnemata 194), Göttingen.

Stephen, Gwendolen (1959), “The Coronis”, in: Scriptorium 13, 1-14.

Stevens, John (1999), "Seneca and Horace: Allegorical Technique in Two Odes to Bacchus (Hor. Carm. 2.19 and Sen. Oed. 403-508), in: Phoenix 53, 281-307.

Strauss Clay, Jenny (2010), “Horace and Lesbian Lyric”, in: Gregson Davis (ed.), A Companion To Horace, Chicester, 128-146.

Thévenaz, Olivier (2002), “Le cygne de Venouse: Horace et la métamorphose de l'Ode II, 20", in: Latomus 61, 861-888.

West, David (1998), Vatis Amici: Horace Odes II, ed., trans. and comm. by D. W., Oxford.

Wiseman, Timothy P. (2015), The Roman Audience: Classical Literature as Social History, Oxford. 